DOI: 10.29166/odontologia.vol22.n2.2020-45-59

URL: http://revistadigital.uce.edu.ec/index.php/odontologia/article/view/2384

PÁG: $45-59$

EDICIÓN: Volumen 22, numero 2 (2020), Ecuador

EDITORIAL: Revista Odontología, Facultad de Odontología,

Universidad Central del Ecuador

ISSN: (on-line) 1390-7468 - (electronico) 1390-9967

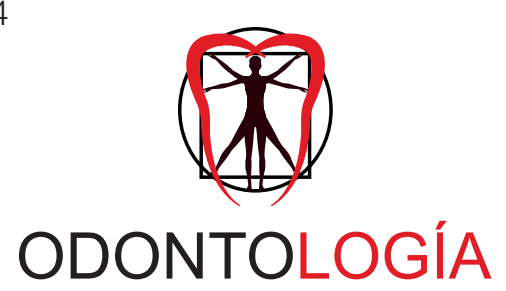

\title{
ARTículos CIENTífico
}

\section{Fatiga cíclica de cuatro sistemas reciprocantes en una canaleta dinámica de raíces simuladas}

Cyclical fatigue of four reciprocating systems in a dynamic dump of
simulating roots

Fadiga cíclica de quatro sistemas reciprocantes em uma com canais simulados

\author{
Daicy Elizabeth Correa Abad'; Paola Daniela Hidalgo Araujo²
}

RECIBIDO: 03/12/2019 ACEPTADO: 10/04/2020 PUBLICADO: 01/07/2020

1. Estudiante de la Facultad de Odontología de la Universidad Central del Ecuador; Quito, Ecuador.

2. PhD en Dentística; Especialista en Endodoncia; Doctora en Odontología de la Facultad de Odontología de la Universidad Central del Ecuador; Quito, Ecuador.

\section{CORRESPONDENCIA}

Daicy Elizabeth Correa Abad

Facultad de Odontología, Universidad Central del Ecuador. Av. América y Universitaria s/n. Quito, Ecuador

danielahidalgoaraujo@yahoo.es 


\section{RESUMEN}

En conductos radiculares curvos, la utilización de limas que eviten desvíos y fracturas del instrumento por fatiga y que mantengan curvaturas originales son aspectos importantes en el tratamiento endodóntico. Objetivo: Se evaluó la resistencia a la fatiga cíclica de cuatro sistemas reciprocantes en una canaleta dinámica que simuló tres curvaturas diferentes. Materiales y Método: Estudio in vitro; la muestra con 48 limas se dividió en cuatro grupos ( $n=12 /$ grupo): WaveOne $\AA$ (WO), WaveOne $₫$ Gold (WOG), Reciproc $($ (R) y Reciproc $\otimes$ Blue (RB), cuatro limas de cada sistema se usaron en una canaleta que simuló tres angulaciones $45^{\circ}, 60^{\circ}$ y $90^{\circ}$; montadas en un motor X-Smart Plus ${ }^{\circledR}$, las limas se introdujeron $23 \mathrm{~mm}$ en los conductos para ser activadas continuamente a 300/500 oscilaciones/minuto hasta que se produjo la fractura. Se registró tiempo y zona de fractura. Se realizó el test Kruskal Wallis con un nivel de confianza del 95\% para las comparaciones. Resultados: RB presentó mayor resistencia a la fatiga cíclica que WO y WOG en todas las angulaciones y que R a $90^{\circ}(p=<0,05)$. R presentó mayor resistencia que WOG a $45^{\circ}$ y $60^{\circ}$, sin embargo, a $90^{\circ}$ WOG fue superior que R y WO $(p<0,05)$. No hubo diferencias en cuanto a la zona de fractura que aconteció en la porción apical. Conclusiones: La resistencia se reduce cuando aumenta el grado de curvatura. RB fue significativamente más resistente a la fatiga cíclica que WO y WOG en todas las angulaciones y que R a $90^{\circ}$. La zona de fractura se produjo en la porción apical de las limas.

Palabras clave: Conducto radicular; fatiga cíclica; resistencia de materiales; resistencia flexional; estrés mecánico.

\section{ABSTRACT}

In the curved canals, the use of files that avoid deviations and fractures of the instrument due to fatigue and that maintain original curvatures are important aspects in endodontic treatment. Objective: The resistance to cyclic fatigue of four reciprocating systems was evaluated in a dynamic gutter that stimulated three different curvatures. Materials and Method: In vitro study, the sample with 48 files was divided into four groups $(n=12$ Igroup): WaveOne $₫(W O)$, WaveOne $®$ Gold (WOG), Reciproc $®(R)$ and Reciproc $®$ Blue (RB), four files from each system were used in a gutter that simulated three angulations 450,60 o and $90 \mathrm{o}$. The files which were mounted on an X-smart Plus $®$ were inserted $23 \mathrm{~mm}$ into the conduits to be continuously activated at 300/500 oscillations per minute until the fracture occurred. Time and fracture zone were recorded. The Krustal Wallis test was performed with a 95\% confidence level for the comparisons. Results: RB presented greater resistance to cyclic fatigue than WO and WOG at 450 and 60o, however, at 90o WOG was higher than R and WO $(p<0.05)$. There were no differences regarding the fracture zone occurred in the apical portion. Conclusions: The resistance decreases when the degree of curvature increases. RB was significantly more resistance to cyclic fatigue than WO and WOG at all angulations and R at 90o. The fracture zone occurred in the apical portion of the files.

Keywords: Root canal; cyclic fatigue; material resistance; flexural strength; mechanical stress.

\section{RESUMO}

Em canais radiculares curvos, o uso de limas que evitem desvios e fraturas do instrumento devido à fadiga e que mantêm as curvaturas originais são aspectos importantes no tratamento endodôntico. Objetivo: avaliar a resistência à fadiga cíclica de quatro sistemas reciprocantes em uma canaleta artificial que simula três curvaturas diferentes. Materiais e Método: estudo in vitro; a amostra com 48 limas foi dividida em quatro grupos ( $\mathrm{n}$ = 12 / grupo): WaveOne $\AA$ (WO), WaveOne $\AA$ Gold (WOG), Reciproc $\AA(R)$ e Reciproc $\AA$ Blue (RB), quatro limas de cada sistema foram usadas em uma canaleta que simulo três angulações $45^{\circ}, 60^{\circ}$ e $90^{\circ}$; se montaram em um motor X Smart Plus $₫$, as limas foram inseridas $23 \mathrm{~mm}$ nos condutos para serem ativadas continuamente a 300/350 oscilações / minuto até ocorrer uma fratura. O tempo e a zona de fratura foram registrados. O teste de Kruskal Wallis foi realizado com um nível de confiança de 95\% para as comparações. Resultados: O RB apresenta maior resistência à fadiga cíclica que o $W O$ e o WOG em todas as angulações e que $\mathrm{R}$ a $90^{\circ}(\mathrm{p}=$ $<0,05)$. R apresentou maior resistência que WOG a $45^{\circ}$ e $60^{\circ}$, no entanto, a $90^{\circ} \mathrm{WO} G$ foi maior que $\mathrm{R}$ e WO $(p<0,05)$. No existiu diferença na zona de fratura que ocorreu na porção apical. Conclusões: a resistência diminui quando o grau de curvatura aumenta. RB foi significativamente mais resistente à fadiga cíclica do que WO e WOG em todos os ângulos e R a $90^{\circ}$. A zona de fratura ocorre na parte apical das limas.

Palavras-chave: Endodontia; fadiga cíclica; resistência de materiais; resistência à flexão; estresse mecânico. 


\section{Introducción}

El tratamiento endodóntico busca devolver la función del órgano dentario por medio de procedimientos químico-mecánicos, el éxito o fracaso del procedimiento dependen directa o indirectamente de la respuesta de estructuras adyacentes ${ }^{1,2}$, ante las alteraciones pulpares y sus repercusiones sobre los tejidos periapicales (3).

Los sistemas de limas fueron fabricados inicialmente en acero al carbono, como la lima K; sin embargo, en conductos radiculares curvos, se presentaban inconvenientes como la rigidez de la aleación y el tiempo de trabajo ${ }^{4,5}$, esto promovió la evolución de los instrumentos para conseguir una adaptación mejor a la anatomía original del conducto radicular ${ }^{6}$.

Con la mejor calidad de los instrumentos disminuyeron eventos iatrogénicos, repisas, cremalleras, perforaciones, transportaciones y desvíos gracias a la elasticidad, flexibilidad y eficacia de corte $^{7}$, se redujo la fatiga cíclica o fractura de las limas ocasionada cuando el eje del instrumento contra la pared interna de la curvatura se comprime, mientras que el lado opuesto se tensiona, el movimiento de la lima dentro del conducto ocasionaría un punto máximo de compresión en la curvatura provocando la fractura inesperada ${ }^{7,8}$.

La aleación NiTi permitió mayor resistencia a la fatiga cíclica de las limas, fue desarrollada por W. F. Buehler, ingeniero metalúrgico (Naval Ordenance Laboratory), quien le dio el nombre de Nitinol (Ni de níquel, Ti de titanio y "nol" por las siglas del laboratorio). Se conocieron las propiedades termodinámicas de la aleación y los conceptos relacionados al efecto de memoria de forma y super-elasticidad a altas temperaturas, así como alta resistencia a la corrosión y biocompatibilidad con el órgano dental. En la actualidad el NiTi es muy utilizado por las características y propiedades específicas de resistencia, amortiguación, elasticidad e histéresis al estrés ${ }^{9-11}$; además, tratamientos

\section{Introduction}

Endodontic treatment seeks to restore the function of the dental organ through chemical-mechanical procedures, the success or failure of the procedure depends directly or indirectly on the response of adjacent structures ${ }^{1,2}$, to pulpal alterations and their repercussions on periapical tissues $^{3}$.

The file systems were initially made of carbon steel, such as the $\mathrm{K}$ file; however, in curved root canals, there were drawbacks such as the rigidity of the alloy and the working time $e^{4,5}$, this promoted the evolution of the instruments to achieve a better adaptation to the original anatomy of the root canal ${ }^{6}$.

With instruments the best quality, iatrogenic events, shelves, racks, perforations, transportation and deviations were reduced thanks to the elasticity, flexibility and cutting efficiency ${ }^{7}$, reducing the cyclic fatigue or files fracture caused when the instrument axis is compressed against the internal wall of the bend, while the opposite side is tensioned, the movement of the file inside the canal would cause a maximum compression point in the bend causing the unexpected fracture ${ }^{7,8}$.

The NiTi alloy allowed greater resistance to the cyclic fatigue of the files, it was developed by WF Buehler, a metallurgical engineer (Naval Ordenance Laboratory), who gave it the name of Nitinol (Ni nickel, Ti titanium and "nol" for short) from the laboratory). The thermodynamic properties of the alloy and the concepts related to the shape memory effect and super-elasticity at high temperatures were known, as well as high resistance to corrosion and biocompatibility with the dental organ. $\mathrm{NiTi}$ is currently widely used due to the characteristics and specific properties of resistance, damping, elasticity and hysteresis to stress $^{9-11}$; In addition, patented 
patentados de calentamiento-enfriamiento han dado a los instrumentos una capa de óxido de titanio que se puede visualizar en su superficie, permitiendo así controlar temperaturas de transición gracias a una aleación en que las limas tienen la capacidad de volver a su estado natural ${ }^{12}$.

WO es un sistema con sección transversal en forma de S, con tres zonas a lo largo de su longitud de trabajo, triangular convexa en la zona apical y dos zonas trapezoidales convexas en la zona media y coronal13,14, permite eliminar la dentina del conducto por medio de su movimiento de $170^{\circ}$ antihorario, $50^{\circ}$ horario y 350 oscilaciones por minuto ${ }^{15}$, está disponible en tres presentaciones: Small, Primary y Large $^{13,16}$, se fabrica con aleación M-Wire ${ }^{17}$.

WOG viene en cuatro presentaciones: SmaII, Primary, Medium y Large ${ }^{18-19}$, a diferencia de su antecesor, presenta una sección transversal en forma de paralelogramo ${ }^{20}$, está fabricada bajo un tratamiento de calentamiento-enfriamiento con una capa superficial de óxido de titanio que le da la coloración dorada ${ }^{19}$.

Los sistemas R y RB presentan una sección transversal en forma de $S^{21,20}$, vienen en tres presentaciones: R25, R40 y R50 a 21, 25 y $31 \mathrm{~mm}^{7,19,20,22}$, están fabricadas con una aleación "M-Wire", mejorada en el caso del sistema $R^{17}$ y un tratamiento de calentamiento-enfriamiento con una capa superficial de óxido de titanio que le da la coloración azulada en los sistemas $\mathrm{RB}^{19,20}$, trabajan con un movimiento de $150^{\circ}$ antihorario, $30^{\circ}$ horario y 300 oscilaciones por minuto, que permite una correcta eliminación de detritus del interior del conducto radicular ${ }^{15}$.

Cuando los conductos radiculares presentan curvaturas pronunciadas, los sistemas reciprocantes se han convertido en primera elección por la ayuda que estos brindan, mejor técnica de instrumentación y menor tiempo de trabajo que la técnica convencional23. heating-cooling treatments have given the instruments a layer of titanium oxide that can be visualized on its surface, thus allowing control of transition temperatures thanks to an alloy in which the files have the ability to return to their natural state ${ }^{12}$.

WO is a system with an S-shaped cross section, with three zones along its working length, triangular convex in the apical zone and two trapezoidal convex zones in the medial and coronal zone ${ }^{13,14}$, allows to eliminate the Due to its $170^{\circ}$ counterclockwise, $50^{\circ}$ hour and 350 oscillations per minute ${ }^{15}$ movement, the dentin of the canal is available in three presentations: Small, Primary and Large $\mathrm{e}^{13,16}$, it is manufactured with M-Wire alloy ${ }^{17}$.

WOG comes in four presentations: Small, Primary, Medium and Large ${ }^{18-19}$, unlike its predecessor, it has a parallelogram-shaped cross section ${ }^{20}$, it is manufactured under a heating-cooling treatment with a surface layer of titanium oxide that gives it the golden coloration ${ }^{19}$.

The $\mathrm{R}$ and RB systems have an S-shaped cross section ${ }^{21,20}$, they come in three presentations: R25, R40 and R50 at 21, 25 and $31 \mathrm{~mm}^{7,19,20,22}$, are manufactured with a "M-Wire" alloy, improved in the case of the $\mathrm{R}^{17}$ system and a heating-cooling treatment with a titanium oxide surface layer that gives it the bluish coloration in the $\mathrm{RB}^{19,20}$ systems, work with a movement of $150^{\circ}$ anti-clockwise, $30^{\circ}$ hourly and 300 oscillations per minute, which allows correct removal of debris from inside the root canal ${ }^{15}$.

When root canals have pronounced curvatures, reciprocating systems have become the first choice due to the help they provide, a better instrumentation technique and less working time than the conventional technique ${ }^{23}$. 
Estudios sobre la resistencia a la fractura de diversos sistemas rotatorios son importantes, en especial cuando existe curvatura radicular; el objetivo del estudio fue evaluar la resistencia a la fatiga cíclica de los sistemas WO, WOG, R y RB, valorando el tiempo de vida útil, grados de curvatura y zona de la lima de fractura en conductos radiculares curvos.

\section{Materiales y métodos}

Estudio in vitro, en conductos simulados se evaluó la resistencia a la fatiga de limas de diferentes sistemas reciprocantes. Para el experimento, se fabricó una canaleta en una caja metálica de $8 \times 14 \mathrm{~cm}$ en la cual se diseñaron tres conductos que simulan curvaturas de dientes naturales: $45^{\circ}, 60^{\circ}$ y $90^{\circ 20}$. Siguiendo las recomendaciones de Mohammad et al. ${ }^{7}$, y Keskin et al. ${ }^{20}$, se crearon tres conductos artificiales de forma cónica, según las dimensiones de los instrumentos a utilizar: $1,5 \mathrm{~mm}$ de diámetro, ángulo de curvatura de $10 \mathrm{~mm}$ desde la punta del instrumental y un radio de curvatura de $5 \mathrm{~mm}$ (figura $\mathrm{N}^{\circ} 1$ ); un canal abierto en la parte superior para la entrada de las limas y un depósito circular al final del canal para la porción de la lima fracturada; la parte anterior se cubrió con un vidrio de $4 \mathrm{~mm}$ de espesor para evitar que la lima resbale o salte $\mathrm{s}^{7,20}$.
Studies on the fracture resistance of various rotary systems are important, especially when there is root curvature; The objective of the study was to evaluate the resistance to cyclical fatigue of the $\mathrm{WO}$, WOG, R and RB systems, evaluating the useful life time, degrees of curvature and area of the fracture file in curved root canals.

\section{Materials and methods}

In vitro study, in simulated ducts, the fatigue resistance of files from different reciprocating systems was evaluated. For the experiment, a gutter was made in an $8 \times 14 \mathrm{~cm}$ metal box in which three canals were designed to simulate natural tooth curvatures: $45^{\circ}, 60^{\circ}$ and $90^{\circ} 20$. Following the recommendations of Mohammad and colls. ${ }^{7}$, and Keskin and colls. ${ }^{20}$, three conical shaped artificial ducts were created, according to the dimensions of the instruments to be used: $1.5 \mathrm{~mm}$ in diameter, a bend angle of $10 \mathrm{~mm}$ from the tip of the instruments and a radius of bend of $5 \mathrm{~mm}$ (figure $\mathrm{N}^{\circ} 1$ ); an open channel at the top for the entrance of the files and a circular deposit at the end of the channel for the portion of the fractured file; the front part was covered with a $4 \mathrm{~mm}$ thick glass to prevent the file from slipping or jumping ${ }^{7,20}$.

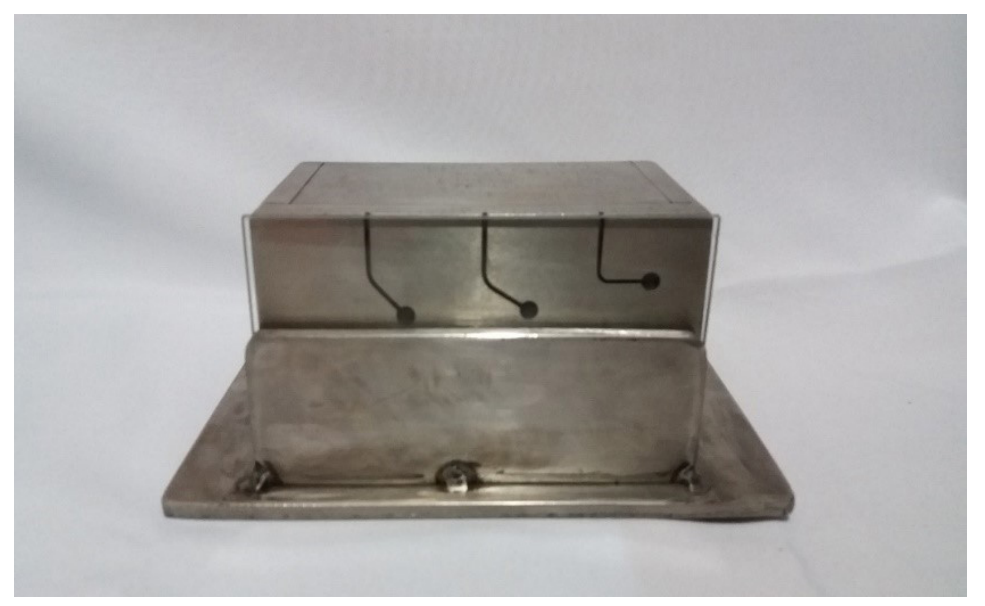

Figura 1. Canaleta dinámica de raíces simuladas; Dynamic gutter of simulated roots

Fuente: Base de datos de la Investigación Elaborado: Los autores 
La muestra se conformó con 48 limas (25/0.25), divididas en cuatro grupos de 12 limas: WO y WOG (Denstply Maillefer, Ballaigues, Switzerland) $\varnothing=25 \mathrm{~mm}$, con conicidad de 0.08 y 0.07 respectivamente, así como, R y RB (VDW, Munich, Germany) $\varnothing=25 \mathrm{~mm}$, conicidad de 0.08. Adicionalmente, 3 subgrupos de 4 limas, fueron utilizados en cada una de las tres curvaturas: $45^{\circ}, 60^{\circ}$ y $90^{\circ}$.

Todas las limas fueron rotadas hasta su fractura y se determinó el tiempo de vida útil y zona de la lima que se fracturó en cada conducto ${ }^{20}$. Las limas de los sistemas reciprocantes fueron nuevas y se utilizaron en un motor X-Smart Plus ${ }^{\circledR}$ (Dentsply Sirona), se excluyeron limas que no guardaron los valores de velocidad en el sistema del motor, vástagos de las limas que no ingresaron correctamente en el contra-ángulo de la pieza de mano del motor o que en el momento de accionarlas se fracturaron fuera del canal artificial.

Se colocó glicerina en el interior de los conductos artificiales para evitar la fricción y calentamiento del metal, luego se instaló la lima en el contra-ángulo y se seleccionó en la biblioteca de limas del motor utilizando el programa preestablecido "Reciproc ALL" diseñado específicamente para los instrumentos R R25 y RB R25 y el programa "WaveOne ALL" diseñado específicamente para los instrumentos WO y WOG, y se accionaron automáticamente a 300 - 500 oscilaciones por minuto según las indicaciones de cada fabricante; todas las limas se activaron a 23 $\mathrm{mm}$ dentro del conducto; por medio de un cronómetro se determinó el tiempo hasta la fractura, además se midió la zona de fractura (zona apical: 1-8 mm, media: 8-16 mm o coronal: $16-23 \mathrm{~mm}$ ) a través de una regla de endodoncia (figura $\mathrm{N}^{\circ} 2$ ).
The sample was made up of 48 files (25 / $0.25)$, divided into four groups of 12 files: WO and WOG (Denstply Maillefer, Ballaigues, Switzerland) $\varnothing=25 \mathrm{~mm}$, with taper of 0.08 and 0.07 respectively, as well as, $R$ and RB (VDW, Munich, Germany) $\varnothing=25$ $\mathrm{mm}$, taper 0.08. Additionally, 3 subgroups of 4 files were used in each of the three curvatures: $45^{\circ}, 60^{\circ}$ and $90^{\circ}$.

All files were rotated until fracture and the useful life time and area of the file that fractured in each conduit were determined ${ }^{20}$. The files of the reciprocating systems were new and were used in an X-Smart Plus $\AA$ (Dentsply Sirona) motor, files that did not save the speed values in the motor system were excluded, as well as the shanks of the files that did not enter correctly in the contra-angle of the motor handpiece or that at the moment of actuation they fractured outside the artificial canal.

Glycerin was placed inside the artificial ducts to prevent friction and heating of the metal, then the file was installed in the contra-angle and selected in the engine file library using the preset program "Reciproc ALL" designed specifically for the R R25 and RB R25 instruments and the "WaveOne ALL" program designed specifically for WO and WOG instruments, and were automatically driven at 300 - 500 oscillations per minute as directed by each manufacturer; all files were activated 23 $\mathrm{mm}$ into the canal; The time to fracture was determined by means of a chronometer, and the fracture area (apical area: 1-8 mm, mean: 8-16 mm or coronal: 16-23 $\mathrm{mm}$ ) was also measured through an endodontic ruler (figure $\mathrm{N}^{\circ} 2$ ). 


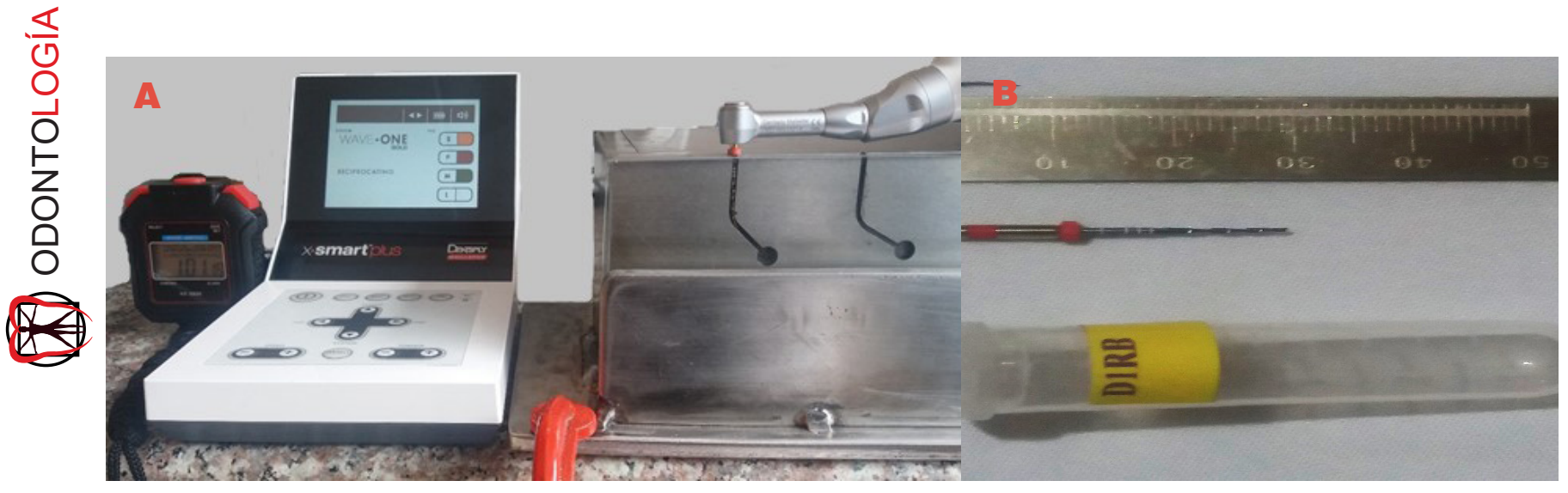

Figura 2. Sistema reciprocante accionado. A. Toma del tiempo B. Medición de la zona fracturada; Powered reciprocating system. A. Time taking B. Measurement of the fractured area

Fuente: Base de datos de la Investigación

Elaborado: Los autores

Los datos fueron analizados y procesados mediante el programa estadístico BioEstat $\AA^{\circledR}$ Versión 5.3, al existir heterocesticidad, se cotejó entre grupos por medio del test Kruskal Wallis con comparaciones de Student-Newman-Keuls y una confiabilidad del 95\%, para determinar la diferencia estadística entre grupos. Se consideraron resultados menores a 0.05 como estadísticamente significativos.

\section{Resultados}

La estadística descriptiva de los sistemas reciprocantes en las diferentes angulaciones demostró que a una curvatura de $45^{\circ}$ existió mayor resistencia a la fatiga cíclica en el sistema RB con un promedio de 1461,0 segundos $( \pm 89,58)$, todas las limas se fracturaron en la porción apical entre 3 y $4 \mathrm{~mm}$ (tabla $\mathrm{N}^{\circ} 1$ ).

The data was analyzed and processed using the BioEstat $\circledast$ Version 5.3 statistical program. As there was heterocesticity, it was compared between groups using the Kruskal Wallis test with Student-Newman-Keuls comparisons and a 95\% reliability, to determine the statistical difference between groups. Results less than 0.05 were considered statistically significant.

\section{Results}

The descriptive statistics of the reciprocating systems at the different angulations showed that at a $45^{\circ}$ bend there was greater resistance to cyclical fatigue in the RB system with an average of 1461.0 seconds ( \pm 89.58), all files were fractured in the apical portion between 3 and $4 \mathrm{~mm}$ (table $\mathrm{N}^{\circ} 1$ ). 
Tabla 1. Medias y desviación estándar a 45; Means and standard deviation at $45^{\circ}$

\begin{tabular}{|l|c|c|c|c|c|}
\hline \multicolumn{7}{|c|}{ Estadística descriptiva a } & $\mathbf{4 5}$ \\
\hline Fatiga - segundos & N & Mínimo & Máximo & Media & $\begin{array}{c}\text { Desv. } \\
\text { Estándar }\end{array}$ \\
\hline Wave One & 4 & 610,00 & 663,00 & 635,75 & 23,14 \\
\hline Wave One Gold & 4 & 485,00 & 536,00 & 513,00 & 22,70 \\
\hline Reciproc & 4 & 982,00 & 1022,00 & 997,50 & 17,61 \\
\hline Reciproc Blue & 4 & 1330,00 & 1532,00 & 1461,00 & 89,58 \\
\hline Fractura - cm & N & Mínimo & Máximo & Media & $\begin{array}{c}\text { Desv. } \\
\text { Estándar }\end{array}$ \\
\hline Wave One & 4 &, 40 &, 40 &, 40 &, 00 \\
\hline Wave One Gold & 4 &, 30 &, 30 &, 30 &, 00 \\
\hline Reciproc & 4 &, 40 &, 50 &, 47 &, 05 \\
\hline Reciproc Blue & 4 &, 40 &, 50 &, 42 &, 05 \\
\hline
\end{tabular}

Fuente: Base de datos de la Investigación

Elaborado: Los autores

Cuando la curvatura fue de $60^{\circ}$, la mayor vida media alcanzó el sistema RB, con un promedio de 1146,0 segundos $( \pm 28,23)$, superior a los otros sistemas; todas las fracturas se presentaron en la porción apical de la lima entre 2 y $6 \mathrm{~mm}$ (tabla $\mathrm{N}^{\circ} 2$ ).
When the curvature was $60^{\circ}$, the longest half-life was reached by the RB system, with an average of 1146.0 seconds ( \pm 28.23), higher than the other systems; all fractures occurred in the apical portion of the file between 2 and $6 \mathrm{~mm}$ (table No. 2).

Tabla 2. Medias y desviación estándar a $60^{\circ}$; Means and standard deviation at $60^{\circ}$

\begin{tabular}{|l|c|c|c|c|c|}
\hline \multicolumn{7}{|c|}{ Estadística descriptiva a $60^{\circ}$} \\
\hline FATIGA - segundos & N & Mínimo & Máximo & Media & Desv. Estándar \\
\hline Wave One & 4 & 790,00 & 837,00 & 811,25 & 19,38 \\
\hline Wave One Gold & 4 & 718,00 & 748,00 & 735,75 & 12,71 \\
\hline Reciproc & 4 & 771,00 & 885,00 & 855,00 & 56,04 \\
\hline Reciproc Blue & 4 & $1.122,00$ & $1.179,00$ & $1.146,00$ & 28,23 \\
\hline Fractura - cm & N & Mínimo & Máximo & Media & Desv. Estándar \\
\hline Wave One & 4 & 0,30 & 0,60 & 0,38 & 0,15 \\
\hline Wave One Gold & 4 & 0,30 & 0,50 & 0,40 & 0,12 \\
\hline Reciproc & 4 & 0,30 & 0,40 & 0,35 & 0,06 \\
\hline Reciproc Blue & 4 & 0,20 & 0,40 & 0,30 & 0,12 \\
\hline
\end{tabular}

Fuente: Base de datos de la Investigación

Elaborado: Los autores

En la mayor curvatura, a $90^{\circ}$, el tiempo se redujo drásticamente en todos los sistemas, existió una mayor resistencia a la fatiga cíclica del sistema RB, donde el tiempo para la fractura tuvo un promedio de 195,0 segundos $( \pm 14,76)$; la zona de fractura se mantuvo en la porción apical para todos los grupos entre 4 y $7 \mathrm{~mm}$ (tabla $\mathrm{N}^{\circ} 3$ ).
At the largest bend, at $90^{\circ}$, the time was drastically reduced in all the systems, there was a greater resistance to cyclic fatigue of the RB system, where the time for fracture averaged 195.0 seconds ( \pm 14.76); the fracture zone was kept in the apical portion for all groups between 4 and $7 \mathrm{~mm}$ (table No. 3). 
Tabla 3. Media y desviación estándar 90; Mean and standard deviation 90

\begin{tabular}{|l|c|c|c|c|c|}
\hline \multicolumn{7}{|c|}{ Estadística descriptiva a $0^{\circ}$} \\
\hline Fatiga - segundos & N & Mínimo & Máximo & Media & $\begin{array}{c}\text { Desv. } \\
\text { Estándar }\end{array}$ \\
\hline Wave One & 4 & 30,00 & 53,00 & 40,25 & 10,69 \\
\hline Wave One Gold & 4 & 72,00 & 110,00 & 85,50 & 17,08 \\
\hline Reciproc & 4 & 69,00 & 76,00 & 72,50 & 3,11 \\
\hline Reciproc Blue & 4 & 173,00 & 204,00 & 195,00 & 14,76 \\
\hline Fractura - cm & N & Mínimo & Máximo & Media & $\begin{array}{c}\text { Desv. } \\
\text { Estándar }\end{array}$ \\
\hline Wave One & 4 & 0,40 & 0,50 & 0,48 & 0,05 \\
\hline Wave One Gold & 4 & 0,50 & 0,60 & 0,53 & 0,05 \\
\hline Reciproc & 4 & 0,40 & 0,50 & 0,48 & 0,05 \\
\hline Reciproc Blue & 4 & 0,50 & 0,70 & 0,65 & 0,10 \\
\hline
\end{tabular}

Fuente: Base de datos de la Investigación

Elaborado: Los autores

La estadística descriptiva mostró que conforme aumenta la angulación disminuye la resistencia a la fatiga. Para determinar si las diferencias fueron estadísticamente significativas se realizó el test de Kruskal Wallis con una confiabilidad del 95\%, comparando con cada una de las tres diferentes angulaciones, se determinó una diferencia significativa entre grupos $(p=<0,01)$. A 90 WO y WOG con $60^{\circ}$ y $R$ y $R B$ con $45^{\circ}$ que fueron lo valores menores en cada grupo (tabla 4).
Descriptive statistics showed that as angulation increases, fatigue resistance decreases. To determine if the differences were statistically significant, the Kruskal Wallis test was performed with 95\% reliability, comparing with each of the three different angulations, a significant difference was determined between groups ( $p=$ $<0.01$ ). At $90^{\circ} \mathrm{WO}$ and $\mathrm{WOG}$ with $60^{\circ}$ and $R$ and $R B$ with $45^{\circ}$, which were the lowest values in each group (table 4).

Tabla 4. Test de Kruskal Wallis para comparación entre angulaciones de cada grupo; Kruskal Wallis test for comparison between angulations of each group

\begin{tabular}{|c|c|c|c|l|}
\hline $\begin{array}{c}\text { Kruskal-Wallis } p= \\
0.0073\end{array}$ & Mediana & Angulación & Z (DESV) & DUNN $p=$ \\
\hline \multirow{4}{*}{ WO } & 635 & $45-60^{\circ}$ & & $\mathrm{ns}$ \\
& 809 & $45-90^{\circ}$ & 2.394 & $\mathrm{~ns}$ \\
& 39 & $60-90^{\circ}$ & & $<0.05$ \\
\hline R & 993 & $45-60^{\circ}$ & & $\mathrm{ns}$ \\
& 882 & $45-90^{\circ}$ & 2.394 & $<0.05$ \\
& 72.5 & $60-90^{\circ}$ & & $\mathrm{ns}$ \\
\hline WOG & 515.5 & $45-60^{\circ}$ & & $\mathrm{ns}$ \\
& 738.5 & $45-90^{\circ}$ & 2.394 & $\mathrm{~ns}$ \\
& 80 & $60-90^{\circ}$ & & $<0.05$ \\
\hline RB & 1491 & $45-60^{\circ}$ & & $\mathrm{ns}$ \\
& 1141.5 & $45-90^{\circ}$ & 2.394 & $<0.05$ \\
& 201.5 & $60-90^{\circ}$ & & $\mathrm{ns}$ \\
\hline
\end{tabular}

Fuente: Base de datos de la Investigación

Elaborado: Los autores 
Para la comparación entre grupos se utilizó la prueba de Kruskal Wallis con una confiabilidad del 95\%. Los resultados determinaron que existía diferencia significativa $(p=$ $<0.05)$. Se utilizó el método de Student-Newman-Keuls para realizar las comparaciones entre los grupos y determinar qué valores eran estadísticamente significativos. Los instrumentos RB se asociaron con los valores de resistencia a la fatiga cíclica más altos entre todos los instrumentos $(P<.05)$ a $90^{\circ}$.

A $45^{\circ}$ y $60^{\circ}$ RB presentó una vida media mayor estadísticamente significativa $(p=$ $<0.05$ ) que WO y WOG, pero no que R. En cambio, a $90^{\circ} \mathrm{RB}$ tuvo estadísticamente mayor resistencia a la fatiga cíclica $(p=<0.05)$ que WO, WOG y R (tabla 5).
For the comparison between groups, the Kruskal Wallis test was used with a reliability of $95 \%$. From the results it was determined that there was a significant difference $(p=<0.05)$. The Student-Newman-Keuls method was used to make comparisons between groups and determine which values were statistically significant. RB instruments were associated with the highest cyclic fatigue resistance values among all instruments $(P<.05)$ at $90^{\circ}$.

At $45^{\circ}$ and $60^{\circ}$, RB presented a statisticaIly significant longer half-life $(p=<0.05)$ than WO and WOG, but not than R. On the other hand, at $90^{\circ} \mathrm{RB}$ it had statistically greater resistance to cyclical fatigue $(p=$ $<0.05$ ) than WO, WOG and R (table 5).

Tabla 5. Comparación entre sistemas en las diferentes angulaciones $\left(45^{\circ}, 60^{\circ}\right.$ y $\left.90^{\circ}\right)$. Test de Kruskal Wallis; Comparison between systems at different angulations $\left(45^{\circ}, 60^{\circ}\right.$ and $\left.90^{\circ}\right)$. Kruskal Wallis test

\begin{tabular}{|l|c|c|c|c|}
\hline \multicolumn{2}{|c|}{$\begin{array}{c}\text { Análisis entre } \\
\text { grupos }\end{array}$} & $45^{\circ} \mathrm{p}=$ & $60^{\circ} \mathrm{p}=$ & $90^{\circ} \mathrm{p}=$ \\
\hline \multicolumn{2}{|c|}{ Krusakal wallis } & 0.0027 & 0.0045 & 0.0039 \\
\hline \multirow{4}{*}{ WO } & WOG & 0.2348 & 0.1375 & 0.0285 \\
& $\mathrm{R}$ & 0.2348 & 0.5525 & 0.1695 \\
\multirow{2}{*}{ WOG } & RB & 0.0175 & 0.0376 & 0.0004 \\
& R & 0.0175 & 0.0376 & 0.414 \\
R & RB & 0.0004 & 0.0004 & 0.0209 \\
\hline
\end{tabular}

Fuente: Base de datos de la Investigación

Elaborado: Los autores

Estadísticamente, a $45^{\circ}$ y $60^{\circ} \mathrm{R}$ fue superior que WOG, pero no que WO; sin embargo, solo RB fue superior a $90^{\circ}$. No hubo diferencias estadísticamente significativas entre $\mathrm{R}$ y WO en ninguna de las angulaciones (tabla $5)$.

En cuanto a la zona de fractura no existió diferencia entre los grupos de estudio, el $100 \%$ de los instrumentos se fracturó en la porción apical, con una media de 3 a 6,5 $\mathrm{mm}$.
Statistically, at $45^{\circ}$ and $60^{\circ} \mathrm{R}$ it was higher than WOG, but not that WO; however, only RB was greater than $90^{\circ}$. There were no statistically significant differences between R and WO in any of the angulations (table 5).

Regarding the fracture area, there was no difference between the study groups, $100 \%$ of the instruments fractured in the apical portion, with an average of 3 to 6.5 $\mathrm{mm}$. 


\section{Discusión}

En base a la metodología propuesta en el presente estudio, se encontró que la resistencia a la fatiga cíclica de las limas disminuye cuando la curvatura es mayor, especialmente a $90^{\circ}$; la vida media de las limas equivaldría a pocos minutos de activación continua, aumentaría el riesgo de fractura con el grado de angulación y tiempo de trabajo. RB demostró ser más resistente a la fatiga cíclica que WO y WOG en todas las angulaciones y que $\mathrm{R}$ a $90^{\circ}$ de curvatura. Todas las limas se fracturaron en la porción apical.

Keskin et al. ${ }^{20}$, presentaron una simulación de la anatomía de las raíces naturales en su tamaño, diámetro, forma, longitud, ángulo y radio de curvatura a través de bloques de resina, sin embargo, la dureza del material en comparación con la dentina era diferente igual que el reblandecimiento por contacto durante el movimiento de la lima dentro del conducto. Por esta razón se utilizó una canaleta dinámica metálica según la metodología propuesta por Mohammad et al. ${ }^{7}$ y Keskin et al. ${ }^{20,24}$.

La canaleta es un modelo dinámico para determinar la fatiga cíclica, hace que las limas aumenten su resistencia, sin embargo, en la parte clínica estas variables son subjetivas, la principal limitación es que las limas pueden entrar holgadamente y necesitar mayor flexibilidad que en un conducto real, sin embargo, el método propuesto es útil ya que permitió ajustar las variables que afectarían la resistencia a la fatiga cíclica como el diámetro del canal, estandarizado a 1,5 mm para logar un mínimo contacto entre la lima, la pared del canal y la longitud de ingreso de la misma ${ }^{7,8}$.

Keskin, et al. ${ }^{33}$, compararon la resistencia a la fatiga cíclica de WOG, R y RB, a $60^{\circ}$ de angulación, en concordancia con nuestro estudio, observaron que RB es superior a WO y R. Sin embargo, en su estudio WOG tuvo mayor resistencia a la fatiga cíclica que $R$, lo difiere de nuestros resultados donde

\section{Discussion}

Based on the methodology proposed in this study, it was found that the resistance to cyclic fatigue of the files decreases when the curvature is greater, especially at $90^{\circ}$; the half-life of the files would be equivalent to a few minutes of continuous activation, increasing the risk of fracture with the degree of angulation and working time. RB proved to be more resistant to cyclic fatigue than WO and WOG at all angulations and $\mathrm{R}$ at $90^{\circ}$ of curvature. All files were fractured in the apical portion.

Keskin and colls. ${ }^{20}$, presented a simulation of the anatomy of natural roots in their size, diameter, shape, length, angle and radius of curvature through resin blocks, however, the hardness of the material compared to dentin was different but equals contact softening during the movement of the file within the canal. For this reason, a metallic dynamic gutter was used according to the methodology proposed by Mohammad et al. ${ }^{7}$ and Keskin et al. ${ }^{20.24}$.

The gutter is a dynamic model to determine cyclical fatigue, it makes the files increase their resistance, however, in the clinical part these variables are subjective, the main limitation is that the files can fit loosely and need more flexibility than in a real duct, however, the proposed method is useful since it allowed adjusting the variables that would affect the resistance to cyclical fatigue such as the diameter of the canal, standardized to $1.5 \mathrm{~mm}$ to achieve a minimum contact between the file, the canal wall and the length of entry of it ${ }^{7.8}$.

Keskin, and colls. ${ }^{33}$, compared the resistance to cyclic fatigue of WOG, R and RB, at $60^{\circ}$ angulation, in agreement with our study; they observed that $\mathrm{RB}$ is superior to WO and R. However, in their study WOG had greater resistance to the cyclic fatigue that $\mathrm{R}$, differs it from our results where 
WO tuvo menor resistencia a $60^{\circ}$. En cuanto a la zona de fractura no encontraron diferencia entre la longitud media de los fragmentos fracturados como fue observado en nuestros datos.

Ha sido explicado por los fabricantes de WOG y RB que los tratamientos térmicos a los que fueron sometidos aumentaron la flexibilidad y la resistencia a la fatiga cíclica de los instrumentos ${ }^{7,13,20}$, no obstante, no encontramos una diferencia significativa a $45^{\circ}$ y $60^{\circ}$ entre $R$ y RB o entre WO y WOG; en cambio al $90^{\circ}$ si se demostró una mayor vida media de WOG y RB que WO y R respectivamente.

Estudios anteriores suelen estudiar a $60^{\circ}$ como una sola referencia de curvatura para determinar la resistencia a la fatiga cícli$\mathrm{ca}^{7,13,20}$, en el presente estudio se realizó la comparación de tres curvaturas, $45^{\circ}, 60^{\circ}$ y $90^{\circ} \mathrm{con}$ un radio de $5 \mathrm{~mm}$, comparación que no se ha realizado anteriormente, estas curvaturas son consideradas como severas según el método de Schneider en 1971. Se determinó que la resistencia a la fatiga cíclica disminuye si aumenta el grado de curvatura.

Mediante este estudio se comprobó que el sistema RB presenta la mayor resistencia a la fatiga cíclica en comparación con $\mathrm{R}$, WO y $W O G$ a $45^{\circ}, 60^{\circ}$ y $90^{\circ}$, resultado que se afirma en un estudio reciente que informó la superioridad en cuanto a la resistencia que presentan RB a $60^{\circ}$, el efecto del tratamiento térmico de la aleación es evidente en los resultados obtenidos ${ }^{19}$.

Se han presentado valores de resistencia de WOG significativamente mayores que los de $\mathrm{R}$ a $60^{\circ 20}$, datos que difieren con los del presente estudio. Nieto y Mendoza ${ }^{21}$, también comparan el sistema WOG con R., manifestaron que WOG presentó mayor resistencia a la fractura a $90^{\circ}$, ya que tuvieron mayor incidencia de puntas deformadas, esto se atribuye a que la aleación oro es menos resistente que la aleación M-Wire tradicional, al contrario, no encontramos di-
WO had less resistance at $60^{\circ}$. Regarding the fracture zone, they found no difference between the mean length of the fractured fragments, as observed in our data.

The manufacturers of WOG and RB have explained that the heat treatments they underwent increased the flexibility and resistance to cyclic fatigue of the instruments ${ }^{7,13,20}$, however, we did not find a significant difference at $45^{\circ}$ and $60^{\circ}$ between $\mathrm{R}$ and RB or between $\mathrm{WO}$ and WOG; on the other hand, at $90^{\circ}$ if a longer half-life of WOG and RB was demonstrated than WO and $R$ respectively.

Previous studies usually have considered $60^{\circ}$ as a single curvature reference to determine resistance to cyclical fatigue $7,13,20$, in the present study, the comparison of three curvatures, $45^{\circ}, 60^{\circ}$ and $90^{\circ}$ was made with a radius of $5 \mathrm{~mm}$, a comparison that has not been made previously, these curvatures are considered as severe according to the method of Schneider in 1971. The resistance to cyclic fatigue was determined to decrease if the degree of curvature increases.

Through this study, it was found that the RB system has the highest resistance to cyclical fatigue compared to $\mathrm{R}, \mathrm{WO}$ and WOG at $45^{\circ}, 60^{\circ}$ and $90^{\circ}$, a result that is confirmed in a recent study that reported superiority in terms of the resistance presented by RB at $60^{\circ}$, the effect of the heat treatment of the alloy is evident in the results obtained ${ }^{19}$.

Resistance values of WOG have been significantly higher than those of $\mathrm{R}$ at $60^{\circ}(20)$, data that differs with those of the present study. Nieto and Mendoza ${ }^{21}$, also compare the WOG system with R., stated that WOG presented greater resistance to fracture at $90^{\circ}$, since they had a higher incidence of deformed tips, this is attributed to the fact that the gold alloy is less resistant than the traditional M-Wire alloy, on the contrary, we found no difference between these 
ferencia entre estos sistemas a $90^{\circ}$.

En el estudio de Pedullá et al. ${ }^{13}$, se comparan los sistemas WO con $\mathrm{R}$, los autores no encontraron diferencias significativas, resultados concordantes con nuestro estudio ya que tampoco observamos diferencia significativa a $45^{\circ}, 60^{\circ}$ y $90^{\circ}$ grados de curvatura.

Similarmente a los resultados obtenidos en los artículos tomados como referencia ${ }^{7,20}$ con los obtenidos en el presente estudio no hubo diferencia significativa en cuanto a la zona de fractura $(\mathrm{mm})$ ya que los cuatro sistemas sufrieron una ruptura a nivel de la zona apical, en una media de 3 a $6,5 \mathrm{~mm}$.

Mohammad et al. ${ }^{7}$, afirman que la velocidad recomendada para el movimiento de los sistemas reciprocantes es de 300 a 500 rpm, valores que fueron utilizados como rangos utilizados en el momento de accionar las limas para valorar la resistencia a la fatiga cíclica.

Aunque la fractura se presentó en la porción apical de las limas, Yared et al. ${ }^{25}$, recomiendan que los sistemas rotatorios de $\mathrm{NiTi}$ pueden utilizarse de forma segura hasta la longitud de trabajo; no obstante, cuando los conductos son muy estrechos o presentan curvaturas en el tercio medio o coronal, no serán de tanto éxito, ya que el tratamiento térmico al que han sido sometidos hace que sean seguros cuando únicamente se curva la porción apical. Esta consideración es importante, si se requiere ampliar será necesario aumentar la conicidad del instrumento o realizar una terminación manual.

Para los sistemas reciprocantes se recomienda que los instrumentos tengan un solo uso; pero se debe considerar que el uso único puede incluir la preparación de al menos 3 conductos radiculares en la mayoría de los dientes molares, que pueden ser complejos, dependiendo de la anatomía del sistema de conducto radicular ${ }^{14}$. Nuestros resultados a $90^{\circ}$ equivalen a pocos minutos de trabajo, sugieren la posibilidad de fractura en raíces de molares con mayor cur- systems at $90^{\circ}$.

In the study by Pedullá and colls. ${ }^{13}$, the WO systems are compared with $\mathrm{R}$, the authors did not find significant differences, results concordant with our study since we also observed no significant difference at $45^{\circ}, 60^{\circ}$ and $90^{\circ}$ degrees of curvature.

In the same way as the results obtained in the articles taken as reference ${ }^{7,20}$ with those obtained in the present study, there was no significant difference regarding the fracture area $(\mathrm{mm})$ since the four systems suffered a rupture at the area level. apical, on an average of 3 to $6.5 \mathrm{~mm}$.

Mohammad and colls. ${ }^{7}$, affirm that the recommended speed for the movement of the reciprocating systems is 300 to 500 rpm, values that were used as ranges used when activating the files to assess the resistance to cyclical fatigue.

Although the fracture occurred in the apical portion of the files, Yared and colls. ${ }^{25}$, recommend that $\mathrm{NiTi}$ rotary systems can be used safely up to the working length; however, when the ducts are very narrow or have curvatures in the middle or coronal third, they will not be as successful, since the heat treatment they have been subjected to makes them safe when only the apical portion is curved. This consideration is important, if expansion is required, it will be necessary to increase the taper of the instrument or perform a manual termination.

For reciprocating systems it is recommended that the instruments have a single use; but it must be considered that the single use may include the preparation of at least 3 root canals in most molar teeth, which can be complex, depending on the anatomy of the root canal system ${ }^{14}$. Our results at $90^{\circ}$ are equivalent to a few minutes of work, suggest the possibility of fracture in the roots of molars with greater curvature where the single use by canal 
vatura donde debería considerarse el uso único por conducto.

En similitud a los resultados presentados, varios estudios han demostrado mayor resistencia a la fractura cíclica de RB, lo que podría determinar que está indicado para trabajar con mayor seguridad en un conducto curvo; sin embargo, nuevas investigaciones deben realizarse procurando incluir otras variables clínicas, además siendo el tamaño de la muestra una limitación en este estudio experimental, otras pesquisas experimentales o ensayos clínicos aleatorizados con una cantidad influyente de muestras deberían permitir encontrar hallazgos más concluyentes.

\section{Conclusión}

La resistencia a la fatiga cíclica de WaveOne, WaveOne Gold, Reciproc y Reciproc Blue se reduce cuando aumenta el grado de curvatura a $90^{\circ}$. La hipótesis nula fue rechazada porque la resistencia a la fatiga cíclica de las limas Reciproc Blue fue significativamente mayor que WaveOne y WaveOne Gold a $45^{\circ}, 60^{\circ}$ y $90^{\circ}$ y que Reciproc a $90^{\circ}$. La zona de fractura se produce en la porción apical de las limas en conductos curvos simulados.

\section{Bibliografía}

1. Weine F. Tratamiento endodoncia. quinta edición ed. Madrid: Editorial Harcourt Brace; 1997.

2. Hulsmann M, Peters O, Dummer P. Mechanical preparation of root canals: shaping goals, techniques and means. Endodontic Topic. 2005; 10(1): p. 30-76.

3. Soares J, Goldberg F. Endodoncia técnica y fundamentos. primera edición ed. Argentina: Editorial Médica Panamericana; 2002.

4. Rodríguez YE. Aleación de Níquel-Titanio y su uso en Endodoncia. Acta Odont. Venez. 2000; 38(1): p. 1-4.

5. Soares J, Goldberg F. Endodoncia Técnica y Fundamentos Madrid: Editorial Médica Panamericana; 2002.

6. Fernández Y, Mendiola C. Evolución de los sis- should be considered.

Similar to the presented results, several studies have shown greater resistance to cyclic fracture of RB, which could determine that it is indicated to work more safely in a curved canal; however, new investigations should be carried out trying to include other clinical variables, in addition to the sample size being a limitation in this experimental study, other experimental investigations or randomized clinical trials with an influential number of samples should allow finding more conclusive findings.

\section{Conclusion}

The cyclic fatigue strength of WaveOne, WaveOne Gold, Reciproc and Reciproc Blue is reduced when the degree of curvature increases to $90^{\circ}$. The null hypothesis was rejected because the resistance to cyclic fatigue of Reciproc Blue files was significantly higher than WaveOne and WaveOne Gold at $45^{\circ}, 60^{\circ}$ and $90^{\circ}$ and that Reciproc at $90^{\circ}$. The fracture zone occurs in the apical portion of the files in simulated curved canals.

temas rotatorios en endodoncia: propiedades y diseño. Rev Estomatol Herediana. 2011; 21(1): p. 51-54.

7. Mohammad RN, Sedigh-Shams M, Abdolrasoulnia S. Cyclic Fatigue Life of Two Single File Engine-Driven Systems in Simulated Curved Canals. IEJ. 2018; 13(1): p. 61-65.

8. Gaitán C, Lara E, Flores H, Pozos A, Méndez V. Current Challanges and Concepts of the Thermomechanical Treatment of Nickel-Titanium Instruments. Odonvtos-Int. J. Dental. 2017; 19(1): p. $51-58$

9. Iacono F, Pirani C, Generali L, Bolelli G, Sassateli $P$, Lusvarghi L, et al. Structural analysis of HyFlex EDM instruments. International Endodontic Journal. 2016;: p. 1-11.

10. Thompson SA. An overview of nickel-titanium alloys used in dentistry. Int. Endod J. 2000; 33(4): 
p. 297-310.

11. Miyay K, Ebihara A, Hayashi $Y$, Doi H, Suda $H$, Yoneyama T. Influence of phase transformation on the torsional and bending properties of nickel-titanium rotatory endodontic instruments. J Endod. 2006; 39(2): p. 119-126.

12. De-Deus G, Nogueira E, Leal V, Goncalves F, Elias C, Plotino G, et al. Blue Thermomechanical Treatment Optimizes Fatigue Resistance and Flexibility of the Reciproc Files. JOE. 2016;: p. 1-5.

13. Pedullá E, Lo Savia F, Boninelli S, Plotino G, Grande N, La Rosa G, et al. Torsional and Cyclic Fatigue Resistance of a New Nickel-Titanium Instruments Manufactured by Electrical Discharge Machining. J. Endod. 2016; 42(1): p. 156-159.

14. Haapasalo M, Shen Y. Evolution of nickel-titanium instruments: from past to future. Endodontic Topic. 2013; 29(1): p. 3-17.

15. Kim HC, Kwak SW, Cheung GP, Ko DH, Chung $\mathrm{SM}$, Lee W. Cyclic fatigue and torsional resistance of two new nickel-titanium instruments used in reciprocation motion: Reciproc versus WaveOne. J Endod. 2012; 38(4): p. 541-544.

16. Gutiérrez JF, Castañeda CM, León V, Ortiz M. Eficiencia del proceso de esterilización de las limas primarias WaveOne. Univ. Odontol. 2015; 34(73): p. 47-51.

17. Nogueira EJ, Hecksber F, Dos Santos H, DeDeus G, Elias CN, Leal VT. Torsional Fatigue Resistance of Blue-treated Reciprocating Instruments. J. Endod. 2018;: p. 1-4.

18. Aranguren J. WaveOne Gold. Surfea el conducto radicular con confianza. IEI.
19. Priori M, Hungaro MA, Monteiro C, Carvalho B, Tanomaru-Filho M, Guerreiro JM, et al. Cyclic fatigue and torsional strength of three different thermally treated reciprocating nickel-titanium instruments. Clinical Oral Investigation. 2018; 22: p. $1865-1871$.

20. Keskin C, Inan U, Demiral M, Keles A. Cyclic Fatigue Resistance of Reciproc Blue, Reciproc, and WaveOne Gold Reciprocating Instruments. J. Endod. 2017; 43(8): p. 1360-1363.

21. Nieto SC, Mendoza PD. Estudio comparativo de los defectos superficiales de las limas Reciproc y WaveOne Gold después de la instrumentación de conductos radiculares en molares extraídos mediante el uso de Microscopía Electrónica de Barrido. Odonto Investigación. 2017;: p. 40-62.

22. Yared GM, Bou DFE, Machtou P. Cyclic fatigue of Profile rotatory instruments after simulated clinical use. J Endod. 2001; 32(1).

23. Guevara C. Repositorio Digital UCE. [Online].; 2017 [cited 2019 Enero 20. Available from: http:// www.dspace.uce.edu.ec/handle/25000/10519.

24. Keskin C, Sariylimaz E, Demarai M. Shaping ability of Reciproc Blue reciprocating instruments with or without glide path in simulated S-haped root canals. J Dent Res Clin Dent Prospect. 2018; 12(1): p. 63-67.

25. Yared G. Reciproc Blue: the new generation of reciprocation. Giornale Italiano di Endodonzia. 2017; 31: p. 96-101.

26. G. Plotino, N.M. Grande, L. Testarelli, G. Gambarini. Cyclic fatigue of Reciproc and WaveOne reciprocating instruments. Int Endod J, 45 (2012), pp. 614-618

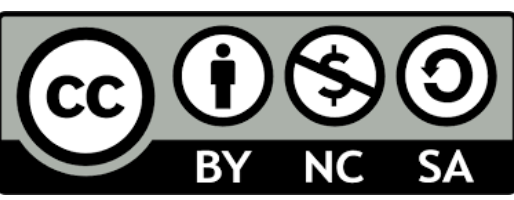

RECONOCIMIENTO-NOCOMERCIAL-COMPARTIRIGUAL CC BY-NC-SA

ESTA LICENCIA PERMITE A OTROS ENTREMEZCLAR, AJUSTAR Y CONSTRUIR A PARTIR DE SU OBRA CON FINES NO COMERCIALES, SIEMPRE Y CUANDO LE RECONOZCAN LA AUTORÍA Y SUS NUEVAS CREACIONES ESTÉN BAJO UNA LICENCIA CON LOS MISMOS TÉRMINOS

\section{CONTRIBUCIÓN DE LOS AUTORES}

CORREA-ABAD D; Concepción y diseño del trabajo, Recolección/obtención de resultados. Análisis e interpretación de datos. Redacción del manuscrito

HIDALGO-ARAUJO P; Concepción y diseño del trabajo. Revisión crítica del manuscrito 